\title{
3 SOCIO-TECHNICAL DESIGN: AN UNFULFILLED PROMISE OR A FUTURE OPPORTUNITY?
}

\author{
Enid Mumford \\ Emeritus Professor \\ Manchester University \\ England
}

\section{Early History}

Socio-technical design is now more than 50 years old. It began with the desire of a group of therapists, researchers, and consultants to use more widely the techniques they had developed to assist war damaged soldiers regain their psychological health and return to civilian life. This group, most of whom had been associated with the London Tavistock Clinic before the war and some of whom were medically qualified, believed that the therapeutic tools and techniques they had developed could usefully be applied to the organization of work in industry. They saw this as restricting and degrading many lower rank employees who were forced to spend their days carrying out simple, routine tasks with no possibility of personal development or job satisfaction.

The Tavistock Institute of Human Relations was founded by this group in London in 1946 with the aid of a grant from the Rockefeller Foundation. It was set up to bring together the psychological and social sciences in a way that benefitted society. In 1948, when the Tavistock Clinic became part of the Health Service, the Institute became a separate organization (Trist and Murray 1993).

Because many of the original members were psychiatrists, all early members of staff were required to undergo psychoanalysis. There was a belief that they had to understand themselves before they could assist with the problems of others. Both the Clinic and the Institute focused on group rather than individual treatment. This was partly because of a shortage of staff but also because group therapy was a recognized and successful method of helping with problems. This therapeutic background meant that staff were interested in results as well as theories. This led them in the direction of "action research," in which analysis and theory is associated with remedial change. The Institute believed that there 
should be "no therapy without research and no research without therapy." Today this could be restated as "no theory without practice, no practice without research." In 1947, a publishing company, Tavistock Publications, was founded and a new journal, Human Relations, was created in association with a research group led by Kurt Lewin and located at the Centre for Group Dynamics at the University of Michigan.

In 1972, the socio-technical movement was formally internationalized by the creation of a Council for the Quality of Working Life, which had members, usually academics, from many countries throughout the world. A number of academic groups became actively interested in socio-technical research. These included the Work Research Institute, Oslo, and groups at the University of Pennsylvania in the United States, York University in Toronto, Canada, and the Centre for Continuing Education in Canberra, Australia. Kurt Lewin, at the University of Michigan in Ann Arbor, also had a considerable influence on thinking and action.

\section{Promises and Possibilities}

When socio-technical design was first developed it was seen by its creators as a means for optimizing the intelligence and skills of human beings and associating these with new technologies in a way that would revolutionize how we live and work.

The socio-technical school believed in flexibility and intellectual growth: that individuals and groups could reorganize and redevelop to meet new challenges in changing environments and that this change process need not be too demanding and difficult. In the 1970s, many companies accepted this message and tried to restructure their procedures and change their cultures to meet new kinds of objectives, both human and technical. Unfortunately, few of these endeavors had any long term success. The attraction and validity of bureaucracy was seen as stronger and safer and the new humanistic approaches as over-risky. This paper will trace the history of socio-technical design as it moved from success to failure, attempt to find some explanations for why an approach that seemed to offer so much never realized its potential in the past, and make some predictions about its relevance for the future.

Socio-technical theory has been continually developed and tested since the Tavistock Institute was founded. Throughout its history, its practitioners have always tried to achieve its two most important objectives: the need to humanize work through the redesign of jobs and democracy at work. In order to realize these goals, the objective of socio-technical design has always been "the joint optimization of the social and technical systems." Human needs must not be forgotten when technical systems are introduced. The social and the technical should, whenever possible, be given equal weight. Over the years, this objective has been interpreted in many different ways but it is still an important design principle.

The technical system was seen as covering technology and its associated work structure. The social system covered the grouping of individuals into teams, coordination, control and boundary management. It also covered the delegation of responsibility to the work group and a reliance on its judgment for many operational decisions. A distinction was made between semi-autonomous groups and self-managing groups. The former are given authority for decision making but may lack the means to achieve this; for example, 
an effective information system. The latter have both authority and the necessary knowledge to control their own activities.

\section{The Evolution of Socio-technical Concepts}

Albert Cherns, an Associate of the Tavistock Institute, described the socio-technical design principles in an article in Human Relations (Cherns 1976). These were:

Principle 1. Compatibility. The process of design must be compatible with its objectives. This means that if the aim is to create democratic work structures, then democratic processes must be used to create these.

Principle 2. Minimal Critical Specification. No more should be specified than is absolutely essential. But the essential must be specified. This is often interpreted as giving employee groups clear objectives but leaving them to decide how to achieve these.

Principle 3. The Socio-technical Criterion. Variances, defined as deviations from expected norms and standards, if they cannot be eliminated must be controlled as close to their point of origin as possible. Problems of this kind should be solved by the group that experiences them and not by another group such as supervision.

Principle 4. The Multifunctionality Principle. Work needs a redundancy of functions for adaptability and learning. For groups to be flexible and able to respond to change, they need a variety of skills. These will be more than their day-to-day activities require.

Principle 5. Boundary Location. Boundaries should facilitate the sharing of knowledge and experience. They should occur where there is a natural discontinuity - time, technology change, etc. in the work process. Boundaries occur where work activities pass from one group to another and a new set of activities or skills is required. All groups should learn from each other despite the existence of the boundary.

Principle 6. Information must go, in the first instance, to the place where it is needed for action. In bureaucratically run companies, information about efficiency at lower levels is collected and given to management. It is preferable for it to go first to the work group whose efficiency is being monitored.

Principle 7. Support Congruence. Systems of social support must be designed to reinforce the desired social behavior. If employees are expected to cooperate with each other, management must also show cooperative behavior.

Principle 8. Design and Human Values. High quality work requires: 
- jobs to be reasonably demanding;

- opportunity to learn;

- an area of decision making;

- social support;

- the opportunity to relate work to social life;

- a job that leads to a desirable future.

Principle 9. Incompletion. The recognition that design is an iterative process. Design never stops. New demands and conditions in the work environment mean that continual rethinking of structures and objectives is required.

William Pasmore, writing in Human Relations (1985), provides a positive assessment of what the socio-technical approach has achieved over the years. $\mathrm{He}$ describes the key insights provided by the early researchers as a recognition that the work system should be seen as a set of activities contributing to an integrated whole and not as a set of individual jobs. As a result, the work group becomes more important than individual job holders. Control should be devolved downwards with the work system regulated by its members, not by external supervisors. This would increase both efficiency and democracy. At the same time, flexibility and the ability to handle new challenges would be enabled through a work design philosophy based on skill redundancy. Work group members should have more skills than normal production required. (Today this is called multi-skilling.) Work activities should not be restricted to routine tasks. Work group members should have as many discretionary as prescribed tasks to perform. And, most importantly, the individual member of any team must be seen as complimentary to any machine, not subordinate to it. This would remove the dictatorship of the moving assembly line. Finally, because an important objective of the socio-technical approach is to increase knowledge, the design of work should lead to an increasing amount of variety for the individual and group so that learning can take place.

\section{International Developments in the 1960s and 1970s}

In Europe in the 1950s and 1960s, industry was weak and was being rebuilt. The strength and productivity of the United States was greatly envied and believed to be a product of better management. European industry was seen as centralized and authoritarian while American industry was becoming more democratic through the influence of the human relations movement. The principal initiators of socio-technical design were the Scandinavian countries. Their approaches had marked similarities. Norway, Sweden, and Denmark, although using different methods and emphasizing different aspects of work, all had a common set of values on what they hoped to achieve (Cooper and Mumford 1979). These values were made explicit in legislation, and management and trade unions were required to cooperate in achieving improvements in the work situation. Work design, although an early manifestation of the desire to improve the quality of working life, was only one aspect of the process of joint decision taking.

In academic circles, a great deal of optimism was associated with these new ventures. Geert Hofstedte, a Dutch expert, believed the humanization of work could become the 
third industrial revolution. He saw the first as the move from muscle power to machinery in the $19^{\text {th }}$ century, the second as the arrival of information technology, and the third as these new approaches to work (Hofstedte 1979).

Let us now examine the experiences of the principal participating countries in more detail.

\subsection{Norway}

Norway was a major pioneer in the humanization of work. In 1962, a group of Norwegian researchers, headed by Einar Thorsrud, who was assisted by Fred Emery then at the Tavistock Institute, initiated what was called "The Norwegian Industrial Democracy Programme." This was a three phase program focusing on, first, creating improved representative systems of joint consultation. These involved the creation of worker directors. Next the program progressed to workplace democracy with employees gaining the authority, power, and resources to change their own work organization, when and where this was appropriate. This led to four major experiments in work restructuring in Norwegian industry.

A national strategy for the humanization of work was a product of these initiatives. This incorporated a Norwegian law on working conditions which gave workers the right to demand jobs conforming to socio-technical principles of good work practice-variety, learning opportunity, own decision power, organizational support, social recognition, and a desirable future. Following on and responding to this came a program for increasing trade union knowledge about technology and, as a result, union bargaining power. This program was led by a group at the Norwegian Computing Centre headed by Christen Nygaard (Eldon 1979). The industrial democracy project was stimulated by the fact that, in the 1970s, much of Norwegian industry was being taken over by multinationals and the environment had become very turbulent.

Although the work design experiments were generally successful, Norway experienced two kinds of resistance to the democratization of work. There was a general belief on the part of workers that any management inspired change must be for the worse, while engineers and technologists saw some of the changes as threatening to their positions and status. These problems have dogged many other change programs.

\subsection{Sweden}

Sweden was in the same situation as Norway and copied its example. By 1973, between 500 and 1,000 work improvement projects were taking place in Swedish industry. Sweden had made its first efforts toward the democratization of working life through the establishment of joint industrial councils in 1946. In the 1970s, the Swedish Government took this further by introducing a "Joint Regulation of Working Life Act." This was implemented in 1977. Both management and unions now needed some guidance on how to proceed in the new areas of codetermination. These were wide ranging covering, the interests of employees, with an emphasis on self-managing groups. They also included better personnel management, better strategic planning and increased productivity 
(Apslund and Otter 1979). A program was agreed that encouraged unions and management to broaden the activities of joint councils so that these could develop new strategies for organizational redesign and business improvement. It was also agreed that unions did not have to rely on the goodwill of management. If management did not make sufficient progress with implementation, then the unions could apply pressure.

A major breakthrough was a move from job design to organizational design. It was in the later 1970s that Per Gyllenhammer created his new "dock assembly" work system at Volvo's Kalmar Plant. This removed the traditional flow line system of car production and substituted group working, with a single group assembling an entire car (Lindholm and Norstedt 1975). The project also developed the idea of worker directors, which the Swedish government required in state enterprises.

An important piece of knowledge acquired during this project was that self-managing groups separated by space and time have more difficulty in coordinating and controlling their activities than those organized bureaucratically. They require excellent information systems to assist their self management. These groups must also be able to set clear production objectives that are acceptable to management. Another problem is how to manage the interface between the workers and the technical systems when there are no foremen, production planners, or quality controllers. The group has to manage all these activities itself. Negotiation now has to replace orders as the primary tool of management and this in itself is very difficult to manage. Success with these new work systems requires the enthusiasm of both management and unions.

\subsection{Denmark}

Formal management/worker cooperation on job content and job design began in Danish companies after the second world war. An agreement in 1947 led to Consultative Committees with equal numbers of employer and employee representatives being set up in a number of large companies (Larsen 1979).

In 1970, a new agreement was made between the Danish Employers Confederation and the Danish Federation of Trade Unions. This required a focus on both production and job satisfaction. It also gave employees the opportunity to become decision partners in the design of their own work situations. A number of factors influenced this move toward work humanization. They included increased interest from management and unions who both saw advantages in a more contented work force. Stable conditions of employment also played their part.

The results, although encouraging, indicated that work humanization could not be achieved without overcoming a number of difficulties. Not all groups of employees had the same interests and wanted the same solutions. A lack of support from senior management or from the trade unions could also slow down progress, as could changes in a company's marketing or economic situation. Danish experience suggested that certain conditions were required for success. These included company stability and financial health. Change was extremely difficult if workers were being laid off. As in Sweden, good relationships and a history of cooperation together with an enthusiastic top management and positive union officials were also necessary. Technology must not act as a design 
constraint and there must be a wage payment system that reinforces group working. Employees should also have a good level of education.

\subsection{France}

In the 1970s, France too was interested in the humanization of work. A survey of 18 companies in 1975 and 1976 showed that a great many jobs had now been enlarged, enriched, or rotated (Trepo 1979). The principal reasons for this effort were a search for production gains together with a recognition of the need to reduce labor problems, which included absenteeism, industrial conflict, and poor quality work. In an attempt to overcome these, the French government introduced legislation requiring employers to demonstrate how they had improved working conditions and how they proposed to improve these further. But the French trade unions were suspicious of these job design efforts, seeing them as yet another possible means to exploit workers.

\subsection{Italy}

Italy was a rather different situation from France. In Italy, the existing rigidly structured and tightly controlled form of work organization, often called Taylorism, was seen as a product of Fascism. The Italian unions, in contrast to unions in other countries, were prepared to fight against this and were determined to secure control over the organization of work (Rollier 1979). The initiative for change, therefore, came from the unions with management as reluctant partners. The union became a major force pressing for change and also the focal point for the promotion and spread of organizational research. Agreements in the early 1970s with companies such as Olivetti and Fiat paved the way for experiments similar to those at Volvo with "production islands" and flexible work cycles. As might be expected, there was resistance from employers, although Olivetti was an exception. The company was converting from engineering to electronics and needed new forms of work organization.

All large Italian companies were afraid of the trade unions and most produced suggestions for work changes, but there was little conviction that the new work system would lead to increases in production. In 1974, Italy had a major economic crisis. Management became frightened of the economic situation and started reshaping their production systems with the aim of breaking the unions. This meant restoring the old Taylorist model and abandoning the proposed changes.

\subsection{Germany}

Strategies to improve the humanization of work in West Germany began in the early 1970s. These were strengthened, in 1973, by a major strike in I. G. Metall over the humanization of work and worker participation. The result of this was that Works Councils now had a say in corporate development and that these subjects became a part of collective bargaining. They also led to discussions between parliament, government, 
and the trade unions (Leminsky 1975). It was increasingly recognized that work was of central importance to a satisfactory life and that rewarding work must contain opportunities for autonomy, freedom, and choice.

This meant that the content of work had to be changed. There must be better training, job enrichment, and the organization of work around groups. Production, repairs, and control would now all be carried out by these groups. These reforms were implemented through new laws and by making Works Councils responsible for their introduction and for monitoring their effectiveness. A program for the humanization of work was introduced by the Federal Ministries of Labor and of Science and Technology in May 1974. This program had three components. First, the development of standards and minimum requirements for machines and workplaces. Second, the development of technologies to meet human requirements. This included computers. Third, case studies and models for the organization of work, based on the socio-technical analysis used in Britain and in Norway. Firms that were willing to introduce new forms of group work, which included more job variety, would receive subsidies to meet part of the cost of these experiments. These changes were facilitated by new legislation, which formalized and ratified workers' rights.

Works Councils were the principal change agents and any plans for reorganization made by the employer had to be agreed by the Works Council. This meant that the trade unions had to train their Works Council members in the management of change and in how to influence policy. The unions also succeeded in gaining Mitbestimmung - the equal representation of labor on supervisory boards and labor directors on executive boards. These became the new worker directors.

This humanization of work program continued successfully for some years but was criticized by socio-technical consultants in other countries for excluding the worker on the shop floor from discussions. Everything was left to the trade unions.

\subsection{Netherlands}

The Netherlands has always taken a lead in work humanization and a major European pioneer in socio-technical design in the 1960s and 1970s was Philips in Eindhoven. The company had many programs that incorporated what the firm called work restructuring and work consultation (Mumford and Beekman 1994). Today we might call these work design and participation. These programs were the responsibility of a special department called Technical Efficiency and Organization.

The commitment of this department to technical change began in the 1960s when the company first noted signs of unrest among blue collar workers who were doing boring and monotonous jobs. Management, and in particular the Director of TEO, were determined to overcome this. Philips believed strongly in the socio-technical principle that the social must have the same importance as the technical and they also understood the relevance of the social sciences to good management.

Philips recognized that work restructuring and participation required major changes in attitude from both management and workers. This new perspective was achieved through meetings, discussions, and lectures, all of which included the Works Council and the trade unions. Although in the 1980s many of these high hopes for the spread of job 
enrichment and employee participation diminished for harsh economic reasons, in the 1970s Philips was providing an inspiring example of socio-technical design (Mumford and Beekman 1994).

\subsection{United Kingdom}

In 1949, the Tavistock Institute pioneered two action research projects. One was a study of joint consultation at the Glacier Metal Company, the other was an investigation of the organization of work in the newly nationalized Coal Board (Jacques 1951). The chief researcher in the first project was Elliott Jacques and, in the second, Ken Bamforth, who had worked as a miner and found many ideas for the redesign of work in his mining experiences (Trist and Murray 1963; Scott, McGivering, and Mumford 1963).

These projects were both successes and failures. New patterns of consultation worked successfully at Glacier but were restricted by the authoritarian attitudes of senior management . Jacques eventually left the Tavistock as he came to believe that the authority structure of British industry, supported by a legal framework, made any fundamental employee democracy difficult if not impossible. The coal mine research had a mixed reception. Group work involving multi-skilling and a degree of self management worked well on experimental faces but was not viewed favorably by the trade union as it conflicted with wage negotiations, which were based on traditional work structures. The Coal Board was not enthusiastic, either, as it did not want trouble with the unions (Mumford 1997).

In 1965, a large scale socio-technical project took place in Shell UK with the assistance of the Tavistock. Shell UK was interested in a new management philosophy that incorporated the idea "that the resources of a company are also the resources of society" (Hill and Emery 1971). The company set out to redefine its objectives in terms of this philosophy. It was decided that these social and business objectives could best be achieved through the use of socio-technical concepts. The Tavistock principle of seeking to achieve the joint optimization of technical and human factors was to guide implementation of the program. This project lasted for four years in the UK and the experiments then continued in Shell plants in Austria, Holland, and Canada. They are still taking place.

\subsection{United States}

In the 1960s and 1970s, the notions of organizational development and the human relations model were extremely popular in the United States but, as the business environment changed, these became less relevant. In 1972, interest in the socio-technical approach was awakened. A decline in productivity was associated with unhappy employees who were alienated from their work. At the same time, competition from Japan and West Germany was increasing. Socio-technical projects in the United States were usually initiated by management without union or worker participation and were directed at increasing organizational effectiveness as well as the quality of working life. Most unions viewed these new policies with suspicion, seeing them as an attempt to 
undermine their interests or to increase productivity to the disadvantage of the worker (Davis and Cherns 1975, p. 5). But there were exceptions. The United Automobile Workers' Union negotiated contracts with General Motors, Ford, and Chrysler in which clauses were included establishing joint management-union committees to improve the quality of working life and to encourage and monitor experiments in job redesign. These projects continued for a number of years.

In the $1980 \mathrm{~s}$, an influential group of American researchers, managers, and consultants formed themselves into the Socio-technical Round Table. This group was originally sponsored by the Society of Manufacturing Engineers and managers from both the Digital Equipment Corporation and General Motors played a major part in its early activities. Socio-technical researchers and practitioners from other countries were invited to join. It played a major role in communicating the socio-technical message to American industry. This group is still active today.

Socio-technical projects were not restricted to Europe and the United States. India was one of the pioneers in work redesign. An early project was carried out in a cotton mill in Ahmedabad, where a group of workers became responsible for a group of looms, work was reorganized and an increase in productivity occurred. These new methods did not last and a visit to the firm by Tavistock researcher A. K. Rice in 1963 found that the old methods had returned. A new management was reluctant to give up power (Rice 1953). However socio-technical initiatives continued, led by an Indian supporter of the Tavistock approach, Processor Nitish De.

\section{Why was Socio-technical Design So Popular in the 1970s?}

By the end of the 1970 s, there was evidence that socio-technical ideas were becoming accepted. The reasons for this interest were similar in all participating countries. Industry was expanding and many firms had labor difficulties. There were problems in obtaining staff and firms were scared of losing those they had.

Projects were spreading from manufacturing to service industries and it appeared that workers were becoming increasingly dissatisfied with the old methods of production. The socio-technical supporters believed that "quality of working life" was an emergent value and that human development could be fostered through work. In their view, the technical imperative would eventually fade away and labor and management would not continue to operate in an adversarial mode. They must and could collaborate. But the sociotechnical group was over optimistic. Progress was not as great as its members believed. Initiatives usually came from individuals at the top of a company anxious to achieve stability and harmony and, even more important, to reduce labor shortages. These initiatives would become fewer once the labor market changed and many were seeking work. A major difficulty during this period was that few trade unions embraced the socio-technical concept. Many saw this as a threat to their power and influence.

A group that acted as an effective communicator and facilitator for socio-technical design at this time was the Quality of Working Life Council. This international group was drawn from many different European countries as well as India, North America, and Australia. It was chaired by Einar Thorsrud, a leading Norwegian academic, and spread 
the quality of work message throughout the world through meetings, training sessions, books and articles. Its members worked with many different companies, initially helping them to introduce socio-technical projects onto their shop floors and later into offices. This group was very influential. It had a common purpose and a strong network of relationships. The members acted as information conduits in their respective countries and through attendance at international conferences.

\section{The 1980s}

Strategies which work well at one time may not be successful at another. Both culture and the business climate can change. Many researchers have seen the 1980s as a disappointing time for organizational innovation. Industry came under pressure to cut costs and socio-technical approaches were increasingly seen as expensive and risky. Computer-assisted clerical and production systems were becoming very popular and an era of what has been described as "computer aided neo-Taylorism" arrived (Moldaschl and Weber 1998). The work of many clerks was routinized as computers moved into offices and a new shop floor technology called lean production took over the car plants. Lean production involved team work of a limited kind, also multi-skilling, direct feedback, and continuous improvement, but work was not made more flexible and interesting. It became faster, more streamlined, and more stressful (Stace 1995). The principal differences between socio-technical design and lean production were the methods for controlling and coordinating work. Socio-technical design created decentralization of control and coordination by the user group. In contrast, lean production focused on the standardization of work processes (Niepce and Molleman 1988).

Although there were few socio-technical initiatives in Britain during this period, a number of researchers, including the author, successfully carried out projects to assist the introduction of new computer systems. All of these followed the socio-technical model. They were participative in that future users at all levels played a major role in the design task, in particular rethinking the design of jobs and work processes for their own departments before new systems were installed. These user design groups, aided by systems analysts who acted as advisers on technical issues, tried to give equal weight to technical and human concerns and introduced team work, multi-skilling and a degree of self management (Mumford 1995, 1996a). The projects included large companies, such as Rolls Royce and ICI, and a number of major banks and hospitals in the UK, together with the Digital Equipment Corporation in the United States. In both countries, these socio-technical design projects were brought to a successful conclusion and implemented. One of the largest and most significant of these was the participative design of XSEL, one of Digital's first expert systems. This was developed to assist the sales force to configure VAX computers and was designed for worldwide implementation (Mumford and MacDonald 1989).

The socio-technical initiative now became dispersed and centered on smaller groups in different countries. The Tavistock retained its influential role in the UK, projects in Scandinavia continued, Eric Trist was influential in the United States and Fred Emery in Australia, the American Socio-technical Round Table was created, and Federico Buttero 
set up a consultancy in Italy. But the international impact was now greatly reduced. Noone was seriously pushing an integrated message internationally.

In the $1980 \mathrm{~s}$, industry's principal objective became cutting costs to compete in increasingly challenging international markets and maintaining or raising the price of their shares. Reducing costs through reducing staff numbers was one way of doing this and socio-technical approaches were seen as having little to offer (Mumford 1996).

\section{The 1990s}

The 1990s proved very frustrating to the exponents of socio-technical design. Companies recognized the need for change and were motivated to make changes but chose methods such as lean production and business process reengineering that took little account of employee needs and did not produce good human results. There were, however, exceptions. Despite difficult economic circumstances, a number of companies in the United States, Europe, and Australia continued with socio-technical projects, remodeling these to fit changing economic and social conditions. Today, the emphasis in Australia is on participative design, Scandinavia favors a democratic dialogue between management and workers, and the expert group of socio-technical consultants belonging to the Socio-technical Round Table assists American companies. Many U.S. projects are based on the development of high commitment and high performance work groups based on the cooperative sharing of power between workers and management.

\section{What Can Socio-technical Design Contribute in the Future?}

Socio-technical theory continues to be of interest to researchers. The Dutch are now developing an approach called Modern Socio-technical Theory, which focuses on production structures as the main determinant of any socio-technical program. The theory behind this approach is that most production systems are over complex and cannot be easily controlled; they need to be simplified (Eijnatten and Zwaan 1998).

Sweden has also been developing the socio-technical concept by bringing the company's business environment into the redesign task. Volvo now uses the phrase "Delivery, Quality and Economic Results" (DQE) to describe its objectives, which are primarily related to cost control. Results are achieved through achieving direct contact between work groups and groups in the external market such as customers and suppliers. The proposed next step is to develop socio-technical systems for business. Adler and Docherty (1998) suggest that the dominant socio-technical research tradition has shifted over time from a social dimension in the 1970s to a technical dimension in the 1980s, greatly influenced by the Dutch, and a business dimension in the 1990's developed by research groups in Scandinavia.

Despite these initiatives in Scandinavia and The Netherlands, few companies in other countries have been interested in extending the use of socio-technical design as a general design principal. The prevalence of down sizing in the 1990s has led to flatter hierarchies in many firms and it has been recognized that innovative companies require highly skilled 
groups who can work as members of high performance teams. These teams give their members responsibility and autonomy but they are usually privileged groups in senior positions, often working in high stress conditions.

Industry is now moving into turbulent waters as globalization increases, technology produces new organizational forms, and an underprivileged section of the world population finds that employment is not available. All of these are a recipe for conflict and possible disaster. The most important contribution socio-technical design can make to this situation is its value system. This tells us that, although technology and organizational structures may change in industry, the rights and needs of all employees must always be given a high priority. These rights and needs include varied and challenging work, good working conditions, learning opportunities, scope for making decisions, good training and supervision, and the potential for making progress in the future. The sociotechnical principles of quality of life and personal control must also be applied to those that are not privileged to have paid employment and who rely on the state for security.

Opportunities for a socio-technical revival may soon be arriving. Millennium society is unlikely to be contented and placid and there are already signs of major conflicts ahead. Commercial success in tomorrow's world requires motivated work forces who are committed to the interests of their employers. This, in turn, requires companies and managers who are dedicated to creating this motivation and recognize what is required for this to be achieved. A return to socio-technical values, objectives, and principals may provide an answer to many of our future problems.

\section{References}

Adler, N., and Docherty, P. "Bringing Business into Socio-technical Theory," Human Relations (51:3), 1998, pp. 319-345.

Apslund, C., and Otter, C. V. "Codetermination through Collective Effort," Chapter 12 in The Quality of Working Life in Western and Eastern Europe, C, L Cooper and E. Mumford (eds.). London: Associated Business Press, 1979.

Cherns, A. "Principles of Socio-technical Design," Human Relations (2:9), 1976, pp. 783-792.

Cooper, C. L., and Mumford, E. "Introduction," in The Quality of Working Life in Western and Eastern Europe. London: Associated Business Press, 1979.

Davis, L., and Cherns, A. Quality of Working Life (Volume 2). Free Press of Glencoe. 1975.

Eijnatten, F. M. v., and Zwaan, A. v. d. "The Dutch Approach to Organizational Design: An Alternative Approach to Business Process Reengineering," Human Relations (51:3), March 1998, pp. 289-318.

Eldon, M. "Three Generations of Work Democracy Experiments in Norway: Beyond Classical Socio-technical System Design," Chapter 11 in The Quality of Working Life in Western and Eastern Europe, C. L. Cooper and E. Mumford (eds.). London: Associated Business Press, 1979.

Hill, P., and Emery, F. Towards a New Philosophy of Management. London: Gower Press, 1971.

Hofstedte, G. "Humanization of Work: The Role of Values in a Third Industrial Revolution," Chapter 12 in The Quality of Working Life in Western and Eastern Europe, C. L. Cooper and E. Mumford (eds.). London: Associated Business Press, 1979.

Jacques, E. The Changing Culture of a Factory. London: Tavistock Publications, 1951.

Larson, H. H. "Humanization of the Work Environment in Denmark," Chapter 7 in The Quality of Working Life in Western and Eastern Europe, C. L. Cooper and E. Mumford (eds.). London: Associated Business Press, 1979. 
Leminsky, G. "Trade Union Strategies for the Humanization of Work in the FRG," in Human Choice and Computers, E. Mumford and H. Sackman (eds.). Amsterdam: North Holland, 1975.

Lindholm, R., and Norstedt, J. P. The Volvo Report. Swedish Employers Confederation, 1975.

Moldaschl, M., and Weber, W. G. "The Three Waves of Industrial Group Work: Historical Reflections on Current Research on Group Work," Human Relations (51:3), March 1998 , pp. 347-388.

Mumford, E. "Assisting Work Restructuring in Complex and Volatile Situations," in Developing Organizational Consultancy, J. E Neumann, K. Kellner, and A. Dawson-Shepherd (eds.). London: Routledge, 1997.

Mumford, E. Effective Systems Design and Requirements Analysis: The ETHICS Method. London: Macmillan, 1995.

Mumford, E. Ethical Tools for Ethical Change. London: Macmillan, 1996.

Mumford, E. "Risky Ideas in the Risk Society," Journal of Information Technology (11), 1996, pp. 321-331.

Mumford, E., and Beekman, G. J. Tools for Change and Progress. Amsterdam: CSG Publications, 1994.

Mumford, E., and MacDonald, B. XSEL's Progress. New York: Wiley, 1989.

Niepce, W., and Molleman, E. "Work Design Issues in Lean Production from a Socio-technical Perspective: Non-Taylorism or the Next Step in Socio-technical Design?" Human Relations (51:3), March 1988, pp. 250-287.

Pasmore, W. A. "Social Science Transformer: The Socio-technical Perspective," Human Relations (48:1), January 1985, pp. 1-22.

Rice, A. K. "Productivity and Social Organization in an Indian Weaving Shed," Human Relations (6), 1953, pp. 297-329.

Rollier, M. "Taylorism and the Italian Unions," Chapter 10 in The Quality of Working Life in Western and Eastern Europe, C. L. Cooper and E. Mumford (eds.). London: Associated Business Press, 1979.

Scott, W., McGivering, I., and Mumford, E. Coal and Conflict. Liverpool: Liverpool University Press, 1963.

Stace, D. A. "Dominant Ideologies, Strategic Change and Sustained Performance," Human Relations (48:1), January 1995, pp. 553-570.

Trepo, G. "Improvement of Working Conditions and Job Design in France," in The Quality of Working Life in Western and Eastern Europe, C. L. Cooper and E. Mumford (eds.). London: Associated Business Press, 1979.

Trist, E, and Murray, H. The Social Engagement of Social Science, Volume 2: The Sociotechnical Perspective. Philadelphia: University of Pennsylvania Press, 1993.

\section{About the Author}

Enid Mumford is an Emeritus Professor of Manchester University, England. She was formerly Professor of Organizational Behavior at the Manchester Business School. Her latest books are Effective Systems Design and Requirements Analysis: The ETHICS Method (London: Macmillan 1995), Ethical Tools for Ethical Change (London: Macmillan, 1996), and Dangerous Decisions: Problem Solving in Tomorrow's World (New York: Kluwer Academic/Plenum, 1999). Enid can be reached by e-mail at enid@em.u-net.com. 